
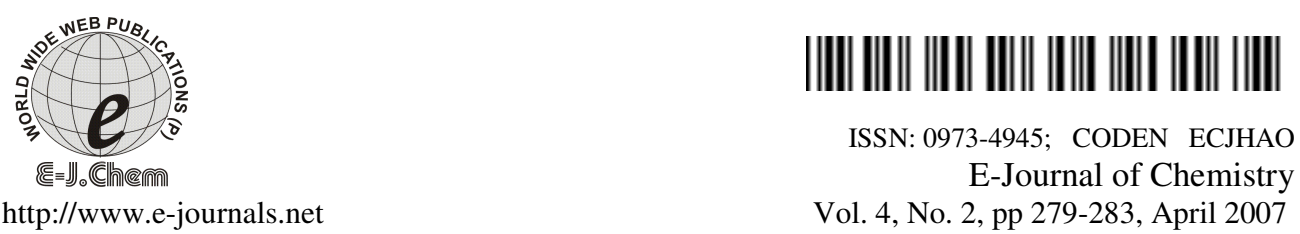

\title{
Kinetics of Oxidation of Glutathione by Micelle Trapped Tris(benzhydroxamato)iron(III)
}

\author{
B. L. HIRAN*, S. S. DULAWAT *, RENU RATHORE and NEERU RATHORE \\ Chemical Kinetics Laboratory, Department of Chemistry, \\ University College of Science, \\ M. L. S. University, Udaipur (Raj) India.313 001. \\ \# Department of Chemistry , B. N. P. G. College, Udaipur. \\ Email : hiranbl@rediffmail.com
}

Received 31 July 2006; Revised 13 October 2006; Accepted 1 November 2006

\begin{abstract}
Kinetics of the oxidation of glutathione (GSH) by micelle Sodium dodecyl sulphate (SDS) trapped tris(benzhydroxamato)iron(III) (TBH) at $\mathrm{pH}$ 3.3 and at $298 \mathrm{~K}$ has been described. The reaction is first order in TBS and GSH. Increase in $\mathrm{pH}$ decreased the rate. Order in $\mathrm{H}^{+}$is one The reaction between TBH and GSH on micellar surface (Stern layer) differs from that occurring in bulk aqueous phase in absence of micelle (SDS). Reactive $\mathrm{FeL}_{3}$ species on micellar surface is $\mathrm{FeL}^{2+}$.
\end{abstract}

Keywords: Kinetics, Micellized tris(benzhydroxamato)iron(III), Sodium dodecyl sulphate, Glutathione.

\section{Introduction}

Tris(benzhydroxamato)iron(III), TBH, has been forwarded as a siderophore model compound ${ }^{1-3}$-a microbial iron transport compound ${ }^{1-8}$. Recently the micelle trapped TBH on sodium dodecyl sulphate, SDS, has been advocated to simulate the dipolar double layer siderophores that is not present in simple soluble hydroxamato complexes. It has been reported that TBH at pH 7.0 is reduced smoothly by sodium dithionite and ascorbic acid 9 . Ascorbic acid and glutathione, both are present in cells of plants, which are known to produce these siderophores (macromolecules containing catecholate and hydroxamate groups for uptake of iron deficiency). Reduction of glutathione, GSH, by the model compound is expected to throw light on the mechanism of iron uptake by siderophores whether it is (i) the ligand exchange with the complex and its subsequent release of iron or (ii) dissociation of the complex, ligation by GSH and subsequent electron transfer or (iii) An associative interchange mechanism with GSH and subsequent electron transfer leading to the release of iron(II). 
These studies have a bearing in the field of bio-inorganic chemistry, particularly when it has been found that glutathione competes effectively with enterobactin ${ }^{10}$ and also reduces iron (III) readily at $\mathrm{pH}<6$.0.This is said to offer a realistic explanation for in vivo removal of iron from enterobactin without necessitating its destruction. It is also pertinent to point out that GSH has a high affinity for iron(II) and renders it likely to be low molecular weight intracellular iron transport compound. Such a role is not likely to be restricted to bacteria ${ }^{11}$ and indeed offers a realistic reason for almost universal distribution of glutathione. It should be noted that evidence for removal of iron by reduction has been previously reported for hydroxamate containing siderophores ${ }^{12-14}$ and catecholate containing siderophore, agrobactin and excreted micrococcus denitrificans ${ }^{15}$. The kinetics of the reduction of GSH by micellised $\mathrm{TBH}$ was undertaken at $\mathrm{pH} 3.3$ where the reaction rate is amenable to conventional kinetic analysis.

\section{Experimental}

Chemicals were of AnalaR specifications. Bezhydroxamic acid was prepared by the reported method $^{16}$ and used after recrystallization and melting point determination. Ferric complex was prepared ${ }^{17}$ using AnalaR ferric nitrate and recrystallized from aqueous ethanol. Glutathione (reduced) (Serva feinbiochemica, Heidelberg) was used as such.

TBH is sparingly soluble in water ${ }^{18}$.It dissolves in water to which sufficient SDS has been added both to exceed the critical micelle concentration (CMC) and to ensure that the concentration of micelle each containing about 60 molecules ${ }^{19}$ exceeds the total iron(III) concentration. CMC of SDS in pure water ${ }^{19,20}$ is $8 \times 10^{-3} \mathrm{~mol} \mathrm{dm}^{-3}$ but lower $2.3 \times 10^{-3} \mathrm{~mol}$ $\mathrm{dm}^{-3}$ for finite ion concentration $\left.{ }^{19,21}\left\{[\mathrm{NaCl}]=0.05 \mathrm{~mol} \mathrm{dm}^{-3}\right]\right\}^{20}$. Micelle concentration was always more than 10 times $[\mathrm{TBH}]$ in every reaction mixture.

\section{Kinetic measurements}

Reaction of micellized TBH with GSH (reduced) was carried out in a thermostatic cell holder spectrophotometrically using Schimadzu make UV-Visible spectrophotometer (Graphicord). The decrease in the concentration of TBH was followed at $485 \mathrm{~nm}$ at $\mathrm{pH} 3.3$ and $298 \mathrm{~K}$. Double distilled water was used to prepare stock solutions and reaction mixtures. GSH solution at $\mathrm{pH} 3.3$ and TBH solution in SDS at $\mathrm{pH} 3.3$ were thermostated separately for half an hour prior to mixing. $\mathrm{HClO}_{4}$ was used to adjust the $\mathrm{pH}$. GSH solutions were freshly prepared every day before use. The reactions were carried out under pseudo-first order conditions i.e. $[\mathrm{GSH}]>10[\mathrm{TBH}]$. Practically no change in the $\mathrm{pH}$ was observed after completion of the reaction.

\section{Results and Discussion}

The rate is first order with respect to TBH when $[\mathrm{Fe}(\mathrm{III})]<10^{-4} \mathrm{~mol} \mathrm{dm}^{-3}$. The second order rate constant at $\mathrm{pH} 3.3$ and $298 \mathrm{~K}$ is $(1.05 \pm 0.04) \times 10^{-2} \mathrm{dm}^{3}$ per mol when [TBH] varies from 1.16 to $2.58 \times 10^{-5} \mathrm{~mol} \mathrm{dm}{ }^{-3}$ and $[\mathrm{GSH}]=[\mathrm{SDS}]=0.02 \mathrm{~mol} \mathrm{dm}^{-3}$. The rate is strictly first order with respect to [GSH] from 1.0 to $8.0 \times 10^{-2} \mathrm{~mol} \mathrm{dm}^{-3}$ with $\mathrm{k}_{2}=\mathrm{k}_{1} /[\mathrm{GSH}]=(0.98 \pm$ $0.04) \times 10^{-2} \mathrm{dm}^{3}$ per mol (Table 1). The rate in aqueous solution in absence of SDS, however, increases asymptotically with increase in $[\mathrm{GSH}]$ and within the concentration range $\left\{[\mathrm{GSH}]=1.0-8.0 \times 10^{-3} \mathrm{~mol} \mathrm{dm}^{-3}\right.$ observed first order rate constant in aqueous solution, $\mathrm{k}_{\mathrm{obs}}$, follows the relation ${ }^{22}$ :

$$
\mathrm{k}_{\mathrm{obs}}=0.55[\mathrm{GSH}]+67.5[\mathrm{GSH}]^{2}
$$


Increase in $\mathrm{pH}[2.0-3.6]$ decreases the rate (Table 2). The order in $\mathrm{H}^{+}$is one in absence of any externally added HL. In aqueous solution in absence of SDS, increase in $\mathrm{pH}$ increases the rate ${ }^{22}$. This is contrary to what has been observed in the micellar pseudo phase (Table 2). The rate is inversely proportional to the concentration of hydroxamic acid [HL] added (Table 2) and levels off at higher [HL] ( Figure 1). All these features suggest that the process proceeds via ligand dissociation as per equilibria:

$$
\begin{aligned}
& \underset{\text { (I) }}{\mathrm{FeL}_{3}}+\mathrm{H}^{+} \stackrel{\mathrm{k}_{1}}{\underset{\mathrm{k}_{2}}{\rightleftharpoons}} \underset{\text { (II) }}{\mathrm{Fe} \mathrm{L}_{2}}{ }^{+}+\mathrm{HL} \\
& \mathrm{FeL}_{2}^{+}+\mathrm{H}^{+} \rightleftharpoons \mathrm{FeL}^{2+}+\mathrm{HL} \\
& \mathrm{FeL}^{2+}+\mathrm{H}^{+} \stackrel{\mathrm{k}_{3}}{\rightleftharpoons} \mathrm{Fe}^{3+}+\mathrm{HL} \\
& \text { (IV) }
\end{aligned}
$$

Table 1. Effect of GSH concentration on rate.

$[\mathrm{TBH}] \times 10^{5}=2.58 \mathrm{~mol} \mathrm{dm}^{-3} ;[\mathrm{SDS}]=0.02 \mathrm{~mol} \mathrm{dm}^{-3} ; \mathrm{pH}=3.3 ;$ Temp. $=298 \mathrm{~K}$

\begin{tabular}{|c|c|c|c|c|c|c|}
\hline$[\mathrm{HL}] \times 10^{2}$ & 1.0 & 2.0 & 3.0 & 4.0 & 5.0 & 9.0 \\
\hline $\mathrm{k}_{\mathrm{obs}} \times 10^{5} \mathrm{~s}^{-1}$ & 5.9 & 2.25 & 1.4 & 1.2 & 0.65 & 0.50 \\
\hline I & 0.760 & 0.932 & 0.948 & 0.960 & 0.968 & 0.984 \\
\hline II & 0.239 & 0.077 & 0.072 & 0.052 & 0.040 & 0.012 \\
\hline $\mathrm{pH}$ & 2.0 & 2.5 & 3.0 & 3.3 & 3.6 & \\
\hline $\mathrm{k}_{\mathrm{obs}} \times 10^{4} \mathrm{~s}^{-1}$ & 26.5 & 9.4 & 3.6 & 2.0 & 1.1 & \\
\hline I & - & - & - & 0.0024 & 0.007 & \\
\hline II & 0.0001 & 0.065 & 0.217 & 0.364 & 0.535 & \\
\hline III & 0.589 & 0.783 & 0.731 & 0.612 & 0.449 & \\
\hline IV & 0.411 & 0.152 & 0.051 & 0.021 & 0.008 & \\
\hline
\end{tabular}

\begin{tabular}{lccccccc}
\hline $\begin{array}{l}{[\mathrm{GSH}] \times 10^{2}} \\
\left(\mathrm{~mol} \mathrm{dm} \mathrm{dm}^{-3}\right)\end{array}$ & 1.0 & 2.0 & 3.0 & 4.0 & 6.0 & 7.0 & 8.0 \\
$\mathrm{k}_{\mathrm{obs}} \times 10^{4}$ & 1.0 & 2.0 & 2.9 & 3.9 & 5.85 & 6.8 & 7.8 \\
$\begin{array}{l}\left(\mathrm{s}^{-1}\right) \\
\mathrm{k}_{2} \times 10^{2}=\mathrm{k}_{\mathrm{obs}} /[\mathrm{GSH}] \\
\left(\mathrm{dm}^{-3} / \mathrm{mol} \mathrm{s}\right)\end{array}$ & 1.0 & 2.0 & 0.966 & 0.975 & 0.975 & 0.971 & 0.975 \\
\hline
\end{tabular}

Table 2. Effect of added $[\mathrm{HL}]$ and $[\mathrm{H}+]$ on the rate of reaction and on mole fraction of $\mathrm{FeL}_{3}$ species.

I, II, III and IV are mole fractions of $\left[\mathrm{FeL}_{3}\right],\left[\mathrm{FeL}^{2+}\right],\left[\mathrm{FeL}^{2+}\right]$ and $\left[\mathrm{Fe}^{3+}\right]$ respectively calculated using $\mathrm{K}$ values at $\mathrm{pH} 3.0$ (ref.18).

At $\mathrm{pH} 3.3$, using the values of the formation constants in aqueous solution ${ }^{18}$ one can calculate the mole fraction of each species existing in equilibrium with each other in absence and presence of added HL. The mole fraction of species (I) to (IV) at $\mathrm{pH} 3.3, \mathrm{~T}=298 \mathrm{~K}$ and $[\mathrm{Fe}(\mathrm{III})]=2.58 \times 10^{-5} \mathrm{M}$ approximates to $0.006,0.415,0.524$ and 0.055 respectively but are in right order. The values are approximate as the $\mathrm{K}$ values used are the values reported ${ }^{18}$ at $\mathrm{pH}$ 3.0.Thus the reactive species is controlled by equilibrium (2). Recently, Lindman et al. ${ }^{23}$, from ESR measurements on vanadyl ion, $\mathrm{VO}^{2+}$, in aqueous solution of SDS have concluded 
that virtually all $\mathrm{VO}^{2+}$ ions become attached to SDS at concentrations only slightly above the CMC. At pH 3.3 the micelle trapped ${ }^{23}$ species is $\mathrm{FeL}^{2+}$ at $[\mathrm{SDS}]=0.02 \mathrm{M}$ which is much above its $\mathrm{CMC}^{20}$. It is very likely that a very strong binding for bivalent ions like $\mathrm{VO}^{2+}$ is a general phenomenon regardless of the nature of micelles, provided that the charge sign of the solute is opposite to that on the micellar surface ${ }^{24}$.This is also supported by the fact that pKa values of weak acids, like HL, on the micellar surface are higher than those in aqueous solution ${ }^{25}$.This favors formation of $\mathrm{FeL}^{2+}$.

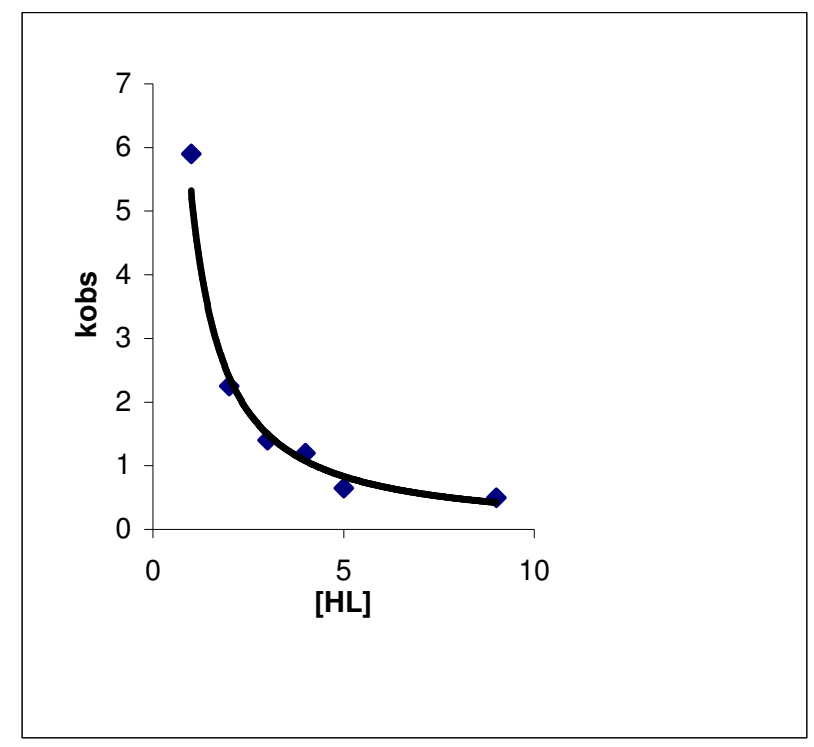

Figure 1. Plot of kobs vs added [HL]

Since bivalent ions are bound strongly to the micelles (vide infra) it seems fair to presume that the complex will be anchored to micelle through its chelating ring penetrating, to some extent, beyond Stern layer into the micellar core. This leads to a situation that encounters between $\mathrm{FeL}^{2+}$ in the micelle phase and GSH in aqueous phase are not at all suitable for the operation of an inner sphere path much less even I (a) process-interchange associative. The reactions between Fe (III) complexes is well known to proceed through I (a) mechanism with rate controlling ligation of the entering group-the GSH here. This rules out the formation of even the ternary complex involving leaving and entering group with metal ion (so called Coordination Foothold) ${ }^{26}$. Whatever be the process, the micellar induced operation of the outer sphere path is ruled out The rates reported for the process be taken as the rate of reaction in the micellar phase between anchored $\mathrm{FeL}^{2+}$ and anchored GSH in specific orientation for a facile removal of an electron from $\mathrm{SH}$ group.

The difference in the rate dependence of the reaction on $[\mathrm{GSH}]$ and $\left[\mathrm{H}^{+}\right]$in aqueous and micellar phases does suggest that a complex reaction in aqueous system can be rendered simpler in micellar phase (the Stern Layer) and that the electron transfer process in micellar pseudo phase may involve appropriate positioning of the electron donor and acceptor species. 


\section{Acknowledgements}

We are thankful to Professor (retired) R. Shanker, M. L. S. University, Udaipur for the discussion. Authors are grateful to Dr. G. L. Mehta for making the data available prior to publication.

\section{References}

1. Raymond K N and Carrano C J Acc.Chem.Res., 1979, 12, 183.

2. Abu-Dari K and Cooper S R and Raymond, K.N. Inorg.Chem.,1978, 17, 3394

3. Abu-Dari K. and Raymond K N Inorg.Chem. 1980, 19, 2034.

4. Neilands B Inorganic Biochemistry Eichhorn, G. (eds.), Elsevier, N.Y. 1973,167.

5. Neilands B . Adv.Chem.Ser.1977, 162, 3.

6. Raymond K N Adv.Chem.Ser. 1977, 162, 33.

7. Tu-Fano T P and Raymond K N J.Am.Chem.Soc.1981, 103,

8. Hider R C., Rahim Mohd, Nor A and Silver J Morrison, I E G and Rees, L V C J.Chem. Soc. ( Dalton Trans).,1981, 609.

9. Kristjansson I., Nielsen F H and Ustrup J Inorg. Chem.,1984, 23, 3674.

10. Hamed M Y, Hider R C and Silver, J Inorg. Chim. Acta 1982, 66, 13.

11. Jacobs A Blood, 1977, 50, 433.

12. Retledge C Biochim. Biophys. Res. Comm.1971, 45, 856.

13. Ieong J and Neilands J B J. Bacterial.,1876, 126, 823.

14. Stranka J G and Emery T Biochem. Biophys. Acta 1979, 569, 277.

15. Tait G H J.Biochem.1975, 146, 191.

16. Dutta R L and Ghosh S J. Indian Chem. Soc. 1967, 44, 820.

17. Epstein L M and Straub D K Inorg. Chem.1969, 8, 453.

18. Schwarzenbach G and Shwarzenbach K Helv. Chim. Acta, 1963, 46, 1390.

19. Fendler J H and Fendler E J Catalysis in Micellar and Macromolecular Systems, N.Y., 1975.

20. Stigter D and Mysels K J J. Phys. Chem.1955, 59, 45.

21. Bruhn H and Holzwarth J Ber. Bunsenges. Phys. Chem.1978, 82, 1006.

23. Stilbs P, Jermer J and Lindman B J. Colloid. Interface Sci.1977, 60,232.

24. Bhalekar A.A and Engberts J B F N J Am. Chem. Soc.1978, 100, 5914.

25. Mukerjee P and Banerjee K K J. Phys. Chem.,1964, 68, 3567.

26. Rorabacher D B and Margerum D W Inorg. Chem., 1964, 3, 382. 


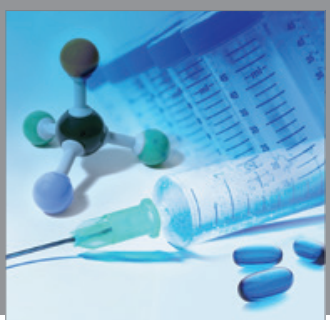

International Journal of

Medicinal Chemistry

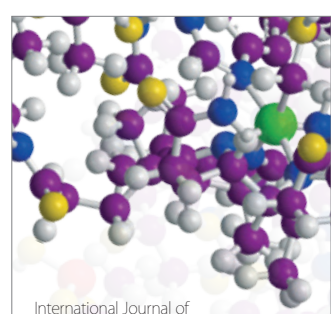

Carbohydrate Chemistry

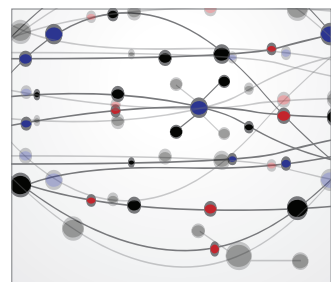

The Scientific World Journal
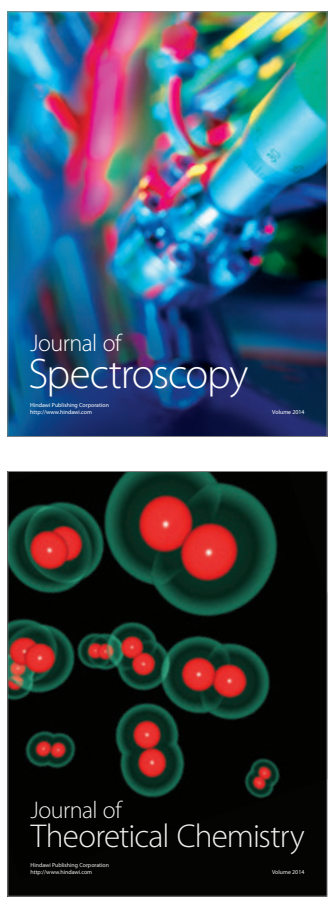
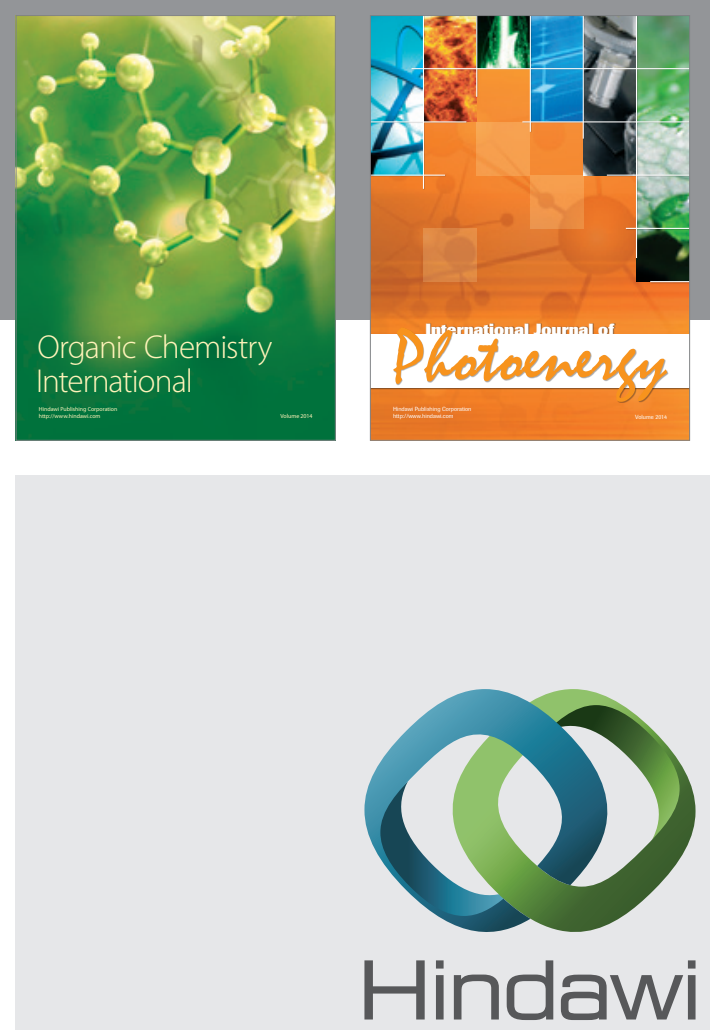

Submit your manuscripts at

http://www.hindawi.com
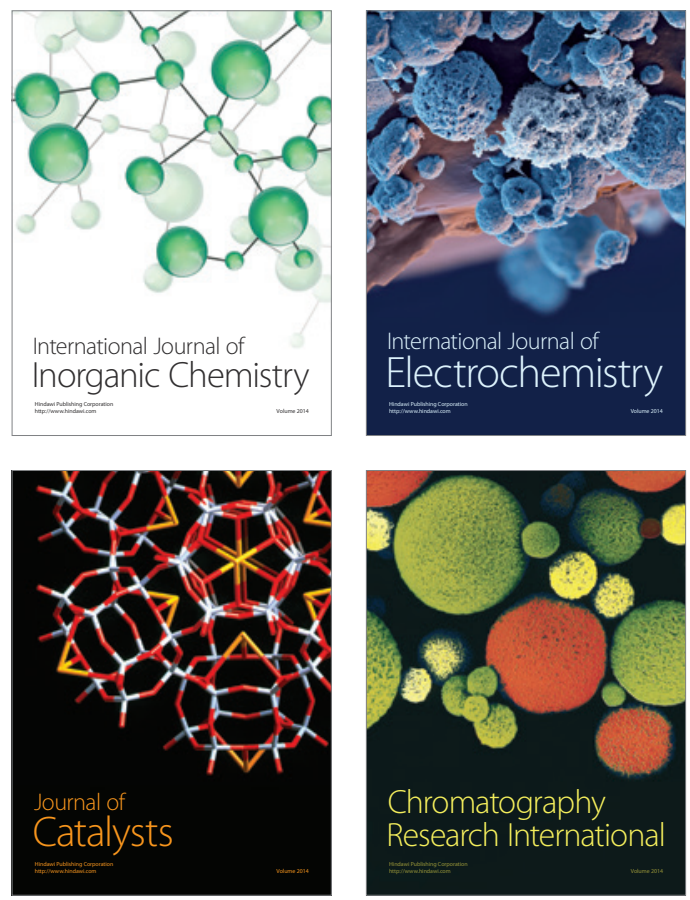
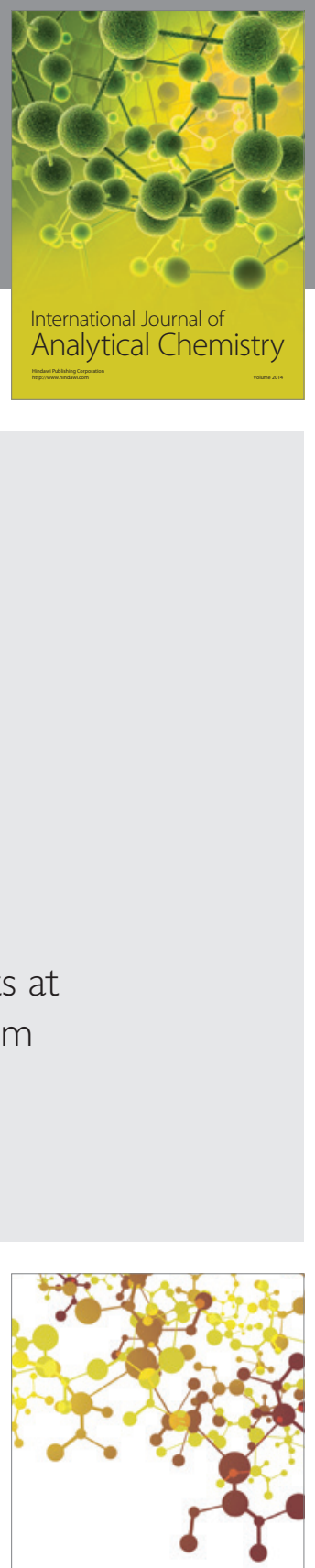

Journal of

Applied Chemistry
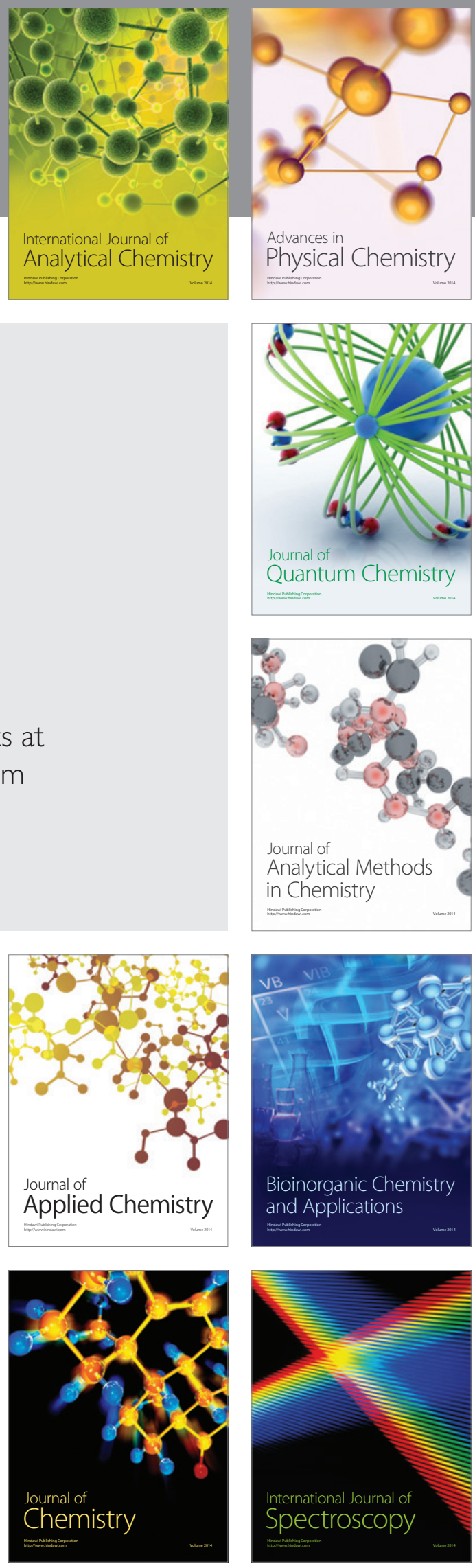